\title{
$\mathrm{FeCl}_{3}$ e o catalisador de facto em acoplamentos carbono-heteroátomos
}

por José C. Barros

catálise por metais tem um papel importante em síntese orgânica, especialmente os acoplamentos cruzados (cross-coupling), que permitem acesso a uma ampla variedade de substâncias de origem naturais e/ou com atividade medicinal.

Geralmente, estas reações de acoplamento requerem metais preciosos como platina ou paládio. Porém há métodos alternativos e de custo mais acessível mediados por níquel, cobre e mais recentemente ferro. Como os sais de ferro possuem menor custo, são não-tóxicos e ambientalmente

toleráveis, estes catalisadores se tornaram uma nova e interessante

metodologia em síntese orgânica.

Inspirados pelo fato das reações catalisadas por cloreto férrico dependerem da pureza do sal e até mesmo de sua origem, Stephen L. Buchwald (Massachussets Institute of Technology - MIT, EUA) e Carsten Bolm (Rheinisch-Westfälische Technische Hochschule Aachen RWTH, Alemanha) conduziram um estudo sistemático de reações de acoplamento carbono-nitrogênio (C$\mathrm{N})$, carbono-oxigênio (C-O) e carbono-enxofre (C-S) catalisadas por este reagente. ${ }^{1}$

Utilizando a reação de acoplamento $\mathrm{C}-\mathrm{N}$ entre 4-iodoanisol e imidazol como um sistema-modelo, $\mathrm{N}, \mathrm{N}^{\prime}$-dimetiletilenodiamina (DMEDA) como ligante, $\mathrm{K}_{3} \mathrm{PO}_{4}$ como base $\mathrm{e}$ tolueno como solvente (Tabela 1) a $135^{\circ} \mathrm{C}$, avaliou-se a influência do
Data de publicação na Web: 05 de Outubro de 2010 Recebido em 03 de Outubro de 2009 Aceito para publicação em 31 de Outubro de 2009

\section{DOI: 10.5935/1984-6835.20100014}

particularmente cobre, poderiam catalisar esta reação. A resposta surge quando óxido cuproso é adicionado ao sistema. Neste caso, quantidades ínfimas de $\mathrm{Cu}_{2} \mathrm{O}$ foram capazes de catalisar a reação mesmo na ausência de $\mathrm{FeCl}_{3}$ (entradas 4 a 6, Tabela 1)!

Esta metodologia foi aplicada em acoplamentos $\mathrm{C}-\mathrm{N}$ para formação de

Tabela 1. N-arilação de pirazol ${ }^{1}$

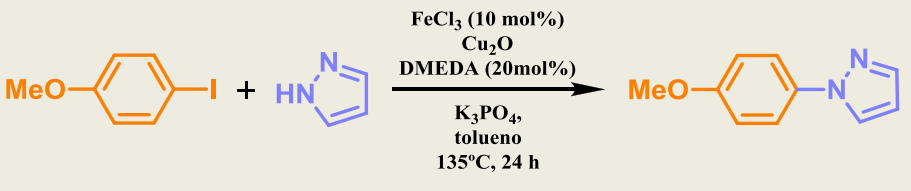

particular e você acha

com ferro, faça

experimentos-controle para cobre",

diz o Prof. Buchwald sobre o trabalho publicado no

Angewandte Chemie International Edition em Julho de 2009.

\begin{tabular}{|c|c|c|}
\hline Entrada & $\mathrm{FeCl}_{3} / \mathrm{Cu}_{2} \mathrm{O}$ & Rdt (\%)* \\
\hline 1 & $\mathrm{FeCl}_{3}>98 \%$ (Merck) & 87 \\
\hline 2 & $\mathrm{FeCl}_{3}>98 \%$ (Aldrich) & 26 \\
\hline 3 & $\mathrm{FeCl}_{3}>99.99 \%$ (Aldrich) & 9 \\
\hline 4 & $\mathrm{FeCl}_{3}>99.99 \%+5 \mathrm{ppm} \mathrm{Cu}_{2} \mathrm{O}$ & 78 \\
\hline 5 & $\mathrm{FeCl}_{3}>99.99 \%+10 \mathrm{ppm} \mathrm{Cu} \mathrm{Cu}_{2} \mathrm{O}$ & 79 \\
\hline 6 & $\begin{array}{l}\text { Ausência de } \mathrm{FeCl}_{3}+\text { ligante }+5 \text { ppm } \\
\mathrm{Cu}_{2} \mathrm{O}\end{array}$ & 77 \\
\hline 7 & $\begin{array}{l}\text { Ausência de } \mathrm{FeCl}_{3}+\text { ausência de ligante } \\
+5 \mathrm{ppm} \mathrm{Cu}_{2} \mathrm{O}\end{array}$ & 23 \\
\hline
\end{tabular}

cloreto férrico anidro $\left(\mathrm{FeCl}_{3}\right)$ de vários graus de pureza e origens. Surpreendentemente, houve diferenças significativas entre os catalisadores da Merck e da Aldrich (entradas 1 e 2, Tabela 1) e mais ainda: quanto mais puro o catalisador, pior se mostrava a reação (entradas 2 e 3, Tabela 1)!

Mas afinal, que espécie de fato catalisou esta reação? Foi proposto que traços de outros metais, amida, C-O e C-S (Tabela 2) fornecendo resultados análogos.

Subsequentemente à publicação do artigo de Buchwald, Trevor Laird destaca em editorial de Org. Proc. Res Dev. ${ }^{2}$ o papel dos contaminantes nas indústrias de química fina, farmacêutica e de produtos agrícolas. A polêmica da catálise por ferro ressurge, ainda, na retratação de um artigo do Tetrahedron envolvendo acoplamentos de Suzuki catalisados

\section{$\mathrm{FeCl}_{3}$ and de facto catalyst in carbon-heteroatom couplings}

Abstract: A summary of the article "On the role of metal contaminants in catalyses with $\mathrm{FeCl}_{3}$ " published in Angew. Chem. Int. Ed. $\mathbf{2 0 0 9}, 48,5586$ and written by Stephen L. Buchwald and Carsten Bolm followed by author's profile and interview are presented. Keywords: $\mathrm{FeCl}_{3}$; catalysis; $\mathrm{C}-\mathrm{N}$ coupling Resumo: Uma resenha para o artigo de Stephen L. Buchwald e Carsten Bolm "On the role of metal contaminants in catalyses with $\mathrm{FeCl}_{3}$ " publicado em Angew. Chem. Int. Ed. 2009, 48, 5586 seguida por perfil do pesquisador e entevista são apresentados.

palavras-chave: $\mathrm{FeCl}_{3}$; catálise; acoplamento $\mathrm{C}-\mathrm{N}$. 
Tabela 2. Comparação de catalisadores em reações de acoplamento C-N, C-O e C-S ${ }^{1}$

\begin{tabular}{|c|c|c|c|}
\hline Produto & & & \\
\hline $\mathrm{FeCl}_{3}>99.99 \%$ & traços & $32 \%$ & $2 \%$ \\
\hline 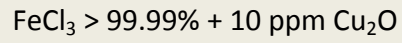 & $99 \%$ & $92 \%$ & $42 \%$ \\
\hline
\end{tabular}

por complexo de ferro e piridina ${ }^{3}$ e na recente definição desta reação uma fábula (cautionary tale). ${ }^{4}$

A síntese orgânica é marcada por histórias de procedimentos que não funcionam ou de difícil reprodução. $\mathrm{O}$ artigo de Buchwald e Bolm ilustrou que traços de impurezas possuem um papel maior do que se pensava anteriormente e podem catalisar reações. Fica a sugestão de Buchwald, na dúvida sobre quem catalisa a reação: "FAÇAM OS EXPERIMENTOSCONTROLE".

É importante destacar que em alguns sistemas os metais de transição podem ser ativos em escala de ppm até ppt, sendo chamados de catalisadores homeopáticos, ${ }^{5,6}$ e consequentemente, uma reação de Suzuki anteriormente publicada como livre de metais ${ }^{7}$ foi revista pois ficou provado que a base $\left(\mathrm{Na}_{2} \mathrm{CO}_{3}\right)$ continha traços de paládio. ${ }^{8}$ Mesmo a quantidade de metal adsorvida nas paredes de um tubo reacional utilizado anteriormente pode catalisar reações de acoplamento (reaction vessel catalysts), ${ }^{9}$ então uma criteriosa limpeza de todo material empregado nos trabalhos de catálise é sempre necessária. ${ }^{10}$

\section{Referências bibliográficas}

${ }^{1}$ Buchwald, S. L.; Bolm, C. Angew. Chem. Int. Ed. 2009, 48, 5586. [CrossRef]

${ }^{2}$ Laird, T. Org. Proc. Res. Dev. 2009, 13, 823. [CrossRef]

\section{Entrevista com o autor do artigo (inglês)}

José: Your recent article in Angew. Chem. Int. Ed. is a systematic study of $\mathrm{FeCl}_{3}$ and its influence in $\mathrm{C}-\mathrm{N}$ coupling. Where does the idea of the manuscript come from?

Buchwald: Several of my former and then current coworkers thought that it was curious that the same ligands and substrates were best for iron and for copper.

José: After your paper, chemists are afraid of using iron mediated reactions. Do you think the chemistry of iron is all incorrect and should be rewritten?

Buchwald: No, just the ones that already have been reported to be successful with copper. I think that this holds true for other metals (e.g. cobalt) as well.

José: Your text has pay attention to the purity of catalyst. Do you think laboratories must from now perform raw material tests before use them? Do you think journals and referees will ask for starting material test in order to accept articles?

Buchwald: No. Even with the smallest amount of copper, we saw reactions equivalent to some of those reported with iron. What is important is to keep in mind what has been done previously. That is, if a reaction has been reported with copper and a particular ligand and you find it now works with iron, do control experiments for copper.

José: The synthetic methodologies developed in your group usually require phosphines, and these compounds are widely known as expensive, toxic, air- and moisture sensitive. At this time, how far are we from some kind of "Greenphos" or "Aquaphos" and is your group is involved in the quest for environmental benign catalysts?

Buchwald: Actually our phosphines are neither air nor moisture sensitive. ${ }^{13}$ While they are currently expensive on a small scale, the price goes down dramatically at a larger scale. It is important to consider the whole process when judging costs and environmental considerations. For example, any reasonably efficient reaction with $\mathrm{Pd}$ and an aryl chloride will undoubtedly be cheaper than a copper-catalyzed one with an aryl iodide. Additionally, one needs to consider the length of time the reaction is run, the nature of the solvent and other things as well.

José: There must be huge differences between the scientific career in the USA and in Brazil, but in your opinion, which are the most important skills for the young chemists? Would you have some advice for us, young Brazilian researchers or PhD students?

Buchwald: For organic chemists the two most important things are to know how to make things and to know how to think about how reactions occur.

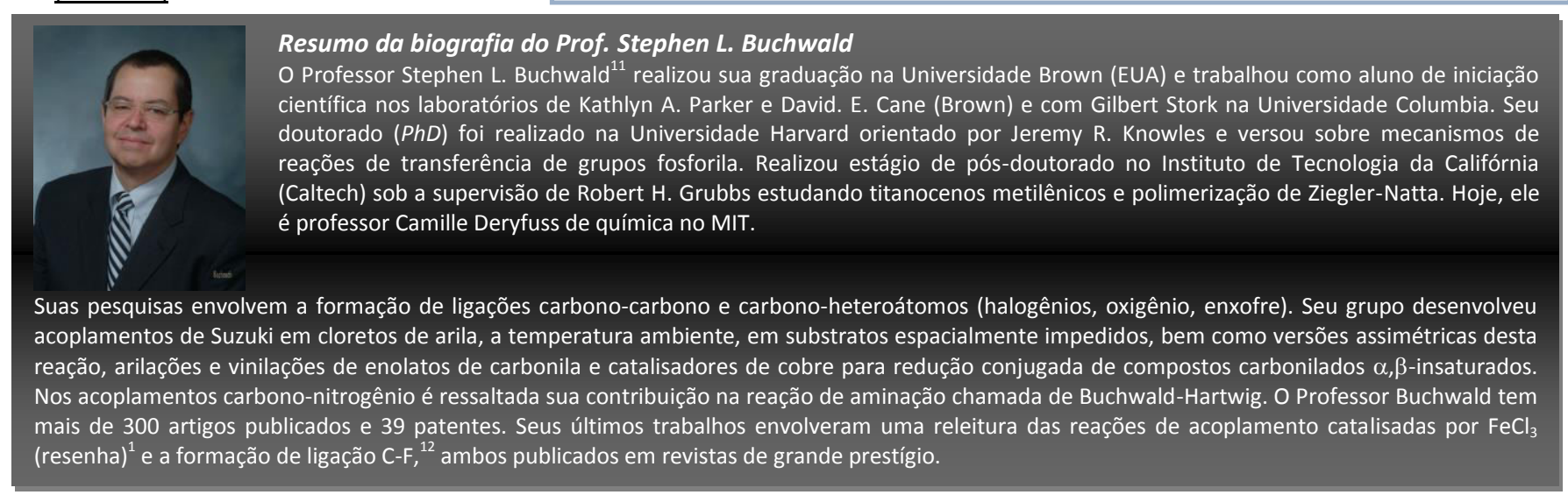


${ }^{3}$ Kylmälä, T.; Valkonen, A.; Rissanen, K.; Xu, Y.; Franzén, R. Tetrahedron Lett. 2009, 50, 5692. [CrossRef]

${ }^{4}$ Bedford, R. B.; Nakamura, M.; Gower, N. J.; Haddow, M. F.; Hall, M. A.; Huwe, M.; Hashimoto, T.; Okopie, R. A. Tetrahedron Lett. 2009, 50, 6110. [CrossRef]

${ }^{5}$ de Vries, A. H. M.; Mulders, J. M. C. A.; Mommers, J. H. M.; Henderickx, H. J. W.; de Vries, J. G. Org. Lett. 2003, 5, 3285. [CrossRef] [PubMed]

6 Alimardanov, A.; Schmieder-van de Vondervoort, L.; de Vries, A. H. M.; de Vries, J. G. Adv. Synth. Catal. 2004, 346, 1812. [CrossRef]

${ }^{7}$ Leadbeater, N. E.; Marco, M. Angew. Chem. Int. Ed. 2003, 42, 1407. [CrossRef]

${ }^{8}$ Arvela, R. K.; Leadbeater, N. E.; Sangi, M. S.; Williams, V. A.; Granados, P.; Singer, R. D. J. Org. Chem. 2005, 70, 161. [CrossRef] [PubMed]

${ }^{9}$ Gruber, A. S.; Pozebon, D.; Monteiro, A. L.; Dupont, J. Tetrahedron Lett. 2001, 42, 7345. [CrossRef]

${ }^{10}$ Dupont e colaboradores empregaram em sequência água régia, $\mathrm{NaOH} 1 \mathrm{M}$, água e acetona ( $3 \times 15 \mathrm{~mL}$ de cada) seguido por secagem em estufa durante $1 \mathrm{~h}$ para suprimir a atividade catalítica de um tubo de reação em reações de acoplamento de Heck. ${ }^{9}$

${ }^{11}$ Sítio "The Buchwald research Group" do Massachussets Institute of Technology - MIT. Disponível em: http://mit.edu/chemistry/buchwald/peop le/bio-slb.html . Acesso em: 30 setembro 2009.

${ }^{12}$ Watson, D. A.; Su, M.; Teverovskiy, G.; Zhang, Y.; García-Fortanet, J.; Kinzel, T.; Buchwald, S. L. Science 2009, 325, 1661. [CrossRef] [PubMed]

3 Barder, T. E.; Buchwald, S. L. J. Am. Chem. Soc. 2007, 129, 5096. [CrossRef] [PubMed]

${ }^{14}$ Tradução livre de JCB

\section{Entrevista com o autor do artigo (português) ${ }^{14}$}

José: Seu recente artigo no Angew. Chem. Int. Ed. é um estudo sistemático do $\mathrm{FeCl}_{3}$ e sua influência nos acoplamentos C-N. Como surgiu a idéia para este manuscrito?

Buchwald: Muitos de meus antigos e atuais colaboradores acharam curioso que os mesmos ligantes e substratos forneciam os melhores resultados tanto para ferro quanto para cobre.

José: Após seu artigo, os químicos estão com medo de utilizar reações mediadas por ferro. O Sr. acredita que a química do ferro está totalmente incorreta e que deva ser reescrita?

Buchwald: Não, somente o que já foi publicado ser possível com cobre. Acredito que isto seja verdadeiro também para outros metais (por exemplo cobalto).

José: Seu artigo deu atenção à pureza do catalisador. O Sr. acredita que a partir de agora os laboratórios terão que realizar testes em sua matéria-prima antes de usá-la? O Sr. acha ainda que jornais e revisores (referees) exigirão testes na matéria-prima para aceitar os artigos?

Buchwald: Não. Mesmo com quantidade ínfima de cobre, nós vemos reações equivalentes àquelas apresentadas com ferro. $\mathrm{O}$ importante é ter em mente o que foi feito anteriormente. Isto é, se uma reação foi publicada com cobre e um ligante em particular e você acha que agora ela funciona com ferro, faça experimentos de controle para cobre.

José: As metodologias de síntese desenvolvidas em seu laboratório usualmente requerem o uso de fosfinas, e estes compostos são largamente reconhecidos como caros, tóxicos, sensíveis ao ar e à umidade. Neste momento, quão distante estamos de algum tipo de "Greenphos" ou "Aquaphos" e o seu grupo está envolvido na busca de catalisadores ambientalmente toleráveis?

Buchwald: Na realidade nossas fosfinas não são sensíveis ao ar nem à umidade. ${ }^{13}$ Apesar delas serem caras em pequena escala, o preço diminui drasticamente em larga escala. É importante considerar todo o processo quando se julga custos e questões ambientais. Por exemplo, qualquer reação razoavelmente eficiente com $\mathrm{Pd}$ e um cloreto de arila será sem dúvida alguma mais barata que uma catalisada por cobre empregando um iodeto de arila. Adicionalmente, é preciso considerar o tempo de reação, a natureza do solvente e outras coisas.

José: Deve haver enormes diferenças entre uma carreira científica nos EUA e no Brasil, mas em sua opinião quais são as habilidades mais importantes para os jovens químicos? O Sr. teria algum conselho para nós, jovens pesquisadores ou pós-graduandos?

Buchwald: Para os químicos orgânicos as duas coisas mais importantes são saber como fazer as coisas e saber como pensar sobre como as reações ocorrem.

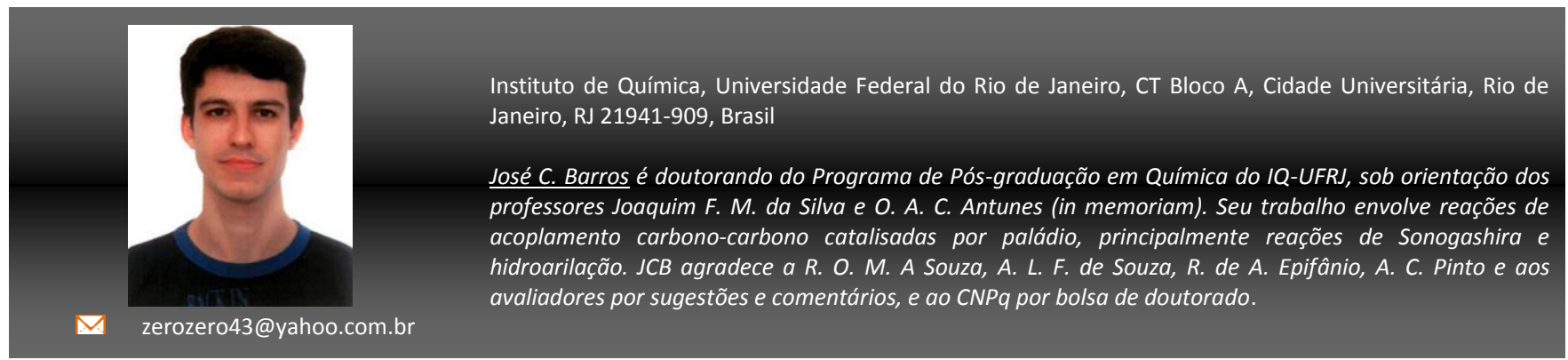

